\section{Review: Characterization and Impact of Supraoptimal Root-zone Temperatures in Container-grown Plants}

\author{
Dewayne L. Ingram ${ }^{1}$ \\ Department of Horticulture, University of Kentucky, N-08F Agri. Science, \\ Center, Lexington, KY 40546-0091
}

John M. Ruter

Department of Horticulture, University of Georgia, 327 Hoke Smith Building, Athens, GA 30602

\section{Chris A. Martin}

Science and Mathematics Faculty, Arizona State University, Mesa, AZ 85212

The high surface area to volume ratio of production containers and the absorption of direct solar radiation by the container surface exposes plant roots to significant temperature fluctuations and extremes during both summer (Ingram, 1981; Ingram et al., 1989; Martin and Ingram, 1992, 1993) and winter (Mathers, 2003) conditions. This report summarizes the progression of our knowledge in the subjects of heat flow in the bio-physical system for container production of landscape plants, the physiological response of plants to supraoptimal root-zone temperatures (RZT), and possible modifications of the production system to alleviate or reduce heat stress. The authors also expect to encourage additional research to address unanswered questions and potential opportunities.

It has long been recognized that supraoptimal RZT limit the growth and quality of plants. Optimum RZT for plant growth were reported in 1949 to be between 26 and $29^{\circ} \mathrm{C}$ and growth was shown to stop in many plants with RZT above $38{ }^{\circ} \mathrm{C}$ (Kramer, 1949). Supraoptimal RZT have been shown to result in reduced plant growth and vigor, heat-induced water stress, direct membrane damage, reduced photosynthesis, modification of respiration rates, alteration of hormones levels and expression, carbon partitioning, nutrient uptake and utilization and alteration of plant architecture. Both direct and indirect types of responses will be discussed in more detail below.

Nursery managers and researchers began to recognize symptoms of heat stress, with increased use of container production systems in the 1950s and 1960s. Temperatures in container substrates were recorded and supraoptimal temperatures in containers were reported as early as 1931 (Jones, 1931) with more detailed measurements made in the

Received for publication 11 Mar. 2014. Accepted for publication 18 Feb. 2015.

${ }^{1}$ To whom reprint requests should be addressed; e-maildingram@uky.edu. 1970s (Fretz, 1972) and 1980s (Ingram, 1981). Ingram et al. (1989) published descriptions of temperature fluctuations in container substrates, critical RZT, symptoms of heat damage in woody ornamentals and cultural practice modifications to address heat stress. Temperature flow in container substrates was modeled extensively in the late 1980s (Martin and Ingram, 1992). Most of the research conducted on temperature fluctuations in containers and plant response to supraoptimal RZT was published before the early 1990s.

Many interesting and unique approaches to providing differential temperature treatments have been studied. These have included whole-plant, growth chamber studies, and experimental protocols providing different temperature treatments to shoots and roots, and systems providing differential temperature environments to portions of the shoots and/or roots. Temperature treatments have been maintained using circulating water baths, air space heated by convection, and resistance heating cables positioned around the root substrate. Some of these approaches will be discussed in detail.

\section{Plant Response to Supraoptimal RZT}

Generally, roots are less tolerant of temperature extremes than shoots (Barr and Pellett, 1972; Wong et al., 1971). Plants evolved in environments where RZT fluctuations and extremes were buffered by the mass of soil in natural landscapes and near constant temperatures at greater depths, which varies with climatic region.

Plants and plant processes can be damaged from long-term exposure to supraoptimal yet sublethal RZT or may be injured immediately from more short-term exposure to a critical extreme RZT. Levitt (1979) described these type of injuries as indirect and direct, respectively. Plant response to supraoptimal RZT in containers have been organized here into those two types of injury.
Direct injury results in an immediate response measureable at the cellular level. The visual symptoms of such injury appear after hours or days, but injury is measureable immediately, usually associated with the loss of membrane integrity. Membrane integrity is lost due to lipid liquidification and/or protein degradation (Wahid et al., 2007). The primary methods to measure membrane integrity resulting from extreme temperature exposure have included the visual observation of browning of tissue over time, measurement of electrical conductivity of electrolytes that leak through damaged membranes into extracellular spaces, and microscopic examination.

It is essential to know the critical RZT that cause direct injury to root tissues when considering methods to reduce heat stress in container-grown plants. Unless modifications can maintain RZT below the critical threshold, such production protocol modifications are in vain. Electrolyte leakage techniques modified from Sullivan (1972) were used to determine the critical RZT for a short exposure, usually 20 or $30 \mathrm{~min}$, of excised roots of a range of plants. A sigmoidal relationship was found between percent electrolyte leakage and temperature treatment, expressed as percent electrolyte leakage $\left(\mathrm{L}_{\mathrm{e}}\right)=\mathrm{z}+\left[(100-\mathrm{z}) /\left(100+\mathrm{e}^{-\mathrm{k}(\mathrm{temp}-\mathrm{B})}\right)\right]$, where $\mathrm{z}$ was the baseline level of electrolyte leakage, B was the temperature corresponding to the midpoint of the response curve, $\mathrm{k}$ was the slope of the line at the midpoint and temp was the treatment temperature (Ingram and Buchanan, 1981, 1984; Martin et al., 1991) The midpoint on the curve was reported as the critical or killing temperature. In most cases these critical temperatures determined in the laboratory were supported by microscopic examination and treatment of whole root systems and observed plant response. A similar technique was used to determine critical temperatures of four woody swamp species [Taxodium distichum (L.) Rich., Nyssa aquatica L., Cephalanthus occidentalis L., and Salix nigra Marshall] (Donovan et al., 1990) and maple cultivars (Acer sp.) (Sibley et al., 1999). Plant species and even cultivars differ in predicted critical high temperatures causing direct root cell membrane injury (Table 1).

Critical temperature for direct injury to cell membranes decreased linearly as exposure duration increased exponentially (Alexandrov, 1964; Ingram, 1985, 1986; Ingram and Ramcharan, 1988; Levitt, 1979). The relationship between the predicted critical temperature $\left(\mathrm{T}_{\mathrm{m}}\right)$ and exposure duration (E) was expressed as $\mathrm{T}_{\mathrm{m}}=\mathrm{c}+\mathrm{d}(\ln \mathrm{E})$, where $\mathrm{c}$ was the intercept and $\mathrm{d}$ was the slope of the fitted line (Ingram, 1985). Using this relationship, the model was expanded to describe the interactive effects of exposure temperature and $\mathrm{E}$ on membrane thermostability as

$$
\mathrm{L}_{\mathrm{e}}=\mathrm{Z}+\left[(\mathrm{x}-\mathrm{z}) /\left(1+\mathrm{e}^{-\mathrm{k}(\mathrm{t}-\mathrm{c}-\mathrm{d} * \operatorname{InE})}\right)\right]
$$

where $\mathrm{x}$ was the highest level of leakage. The published graphic presentation of that model 
describing treatment temperatures and exposure duration interactions on $\mathrm{L}_{\mathrm{e}}$ for Pittosporum tobira Thunb. (pittosporum) is shown in Figure 1.

Predicted critical temperatures for pittosporum root cell membranes ranges from $52.2 \pm$

$0.2^{\circ} \mathrm{C}$ for $30 \mathrm{~min}$ to $46.3 \pm 0.2{ }^{\circ} \mathrm{C}$ for a 300 min exposure. Predicted critical temperatures for Ilex crenata Thunb. 'Helleri' ('Helleri' holly) and Ilex vomitoria Ait. 'Schillings' ('Schillings' holly) were $51.0 \pm 0.8{ }^{\circ} \mathrm{C}$ and

Table 1. Predicted critical temperatures causing direct membrane damage for excised roots of selected plants for a 20-, 30-, or 35-min exposure [from reports of Ingram et al. (1981, 1985, 1986, 1988), Martin et al. (1991), Sibley et al. (1999), and Donovan et al. (1990)].

\begin{tabular}{lc}
\hline Plant & Predicted critical temp $\left({ }^{\circ} \mathrm{C}\right) /$ Exposure $(\mathrm{min})$ \\
\hline Acacia smallii & $45.3 \pm 1.8 / 35$ \\
Acer rubrum & $52.6 \pm 0.2 / 30$ \\
Acer $\times$ freemanii & $52.9 \pm 0.2 / 30$ \\
Cephalanthus occidentalis & $51.0 \pm 0.2 / 30$ \\
Cercidium floridum & $49.4 \pm 0.8 / 35$ \\
Citrus aurantium (Sour orange) & $52.5 \pm 0.7 / 20$ \\
C. citrange $\times$ Poncirus trifoliata ('Carrizo' citrange) & $51.6 \pm 0.5 / 20$ \\
C. paradisi $\times$ P. trifoliata ('Swingle' citrumelo) & $53.5 \pm 0.5 / 20$ \\
Dracaena marginata 'Tricolor' & $57.7 \pm 0.9 / 30$ \\
Ilex vomitoria 'Schillings' & $52.6 \pm 0.7 / 30$ \\
Ilex crenata 'Helleri' & $51.0 \pm 0.8 / 30$ \\
Ilex crenata 'Rotundifolia' & $47.8 \pm 0.5 / 20$ \\
Ilex cornuta 'Dwarf Burfordii' & $46.5 \pm 0.5 / 20$ \\
Illicium parviflorum & $50.5 \pm 0.5 / 20$ \\
Ixora coccinea & $55.5 \pm 0.7 / 30$ \\
Juniperus chinensis 'Parsonii' & $48.5 \pm 0.5 / 20$ \\
Magnolia grandiflora 'St. Mary' & $52.5 \pm 0.9 / 30$ \\
Musa sp. 'Grand Naine' & $53.4 \pm 0.7 / 30$ \\
Nyssa aquatica & $50.9 \pm 0.2 / 30$ \\
Pittosporum tobira & $52.2 \pm 0.2 / 30$ \\
Salix nigra & $45.4 \pm 0.4 / 30$ \\
Taxodium distichum & $46.6 \pm 0.6 / 30$ \\
\hline
\end{tabular}

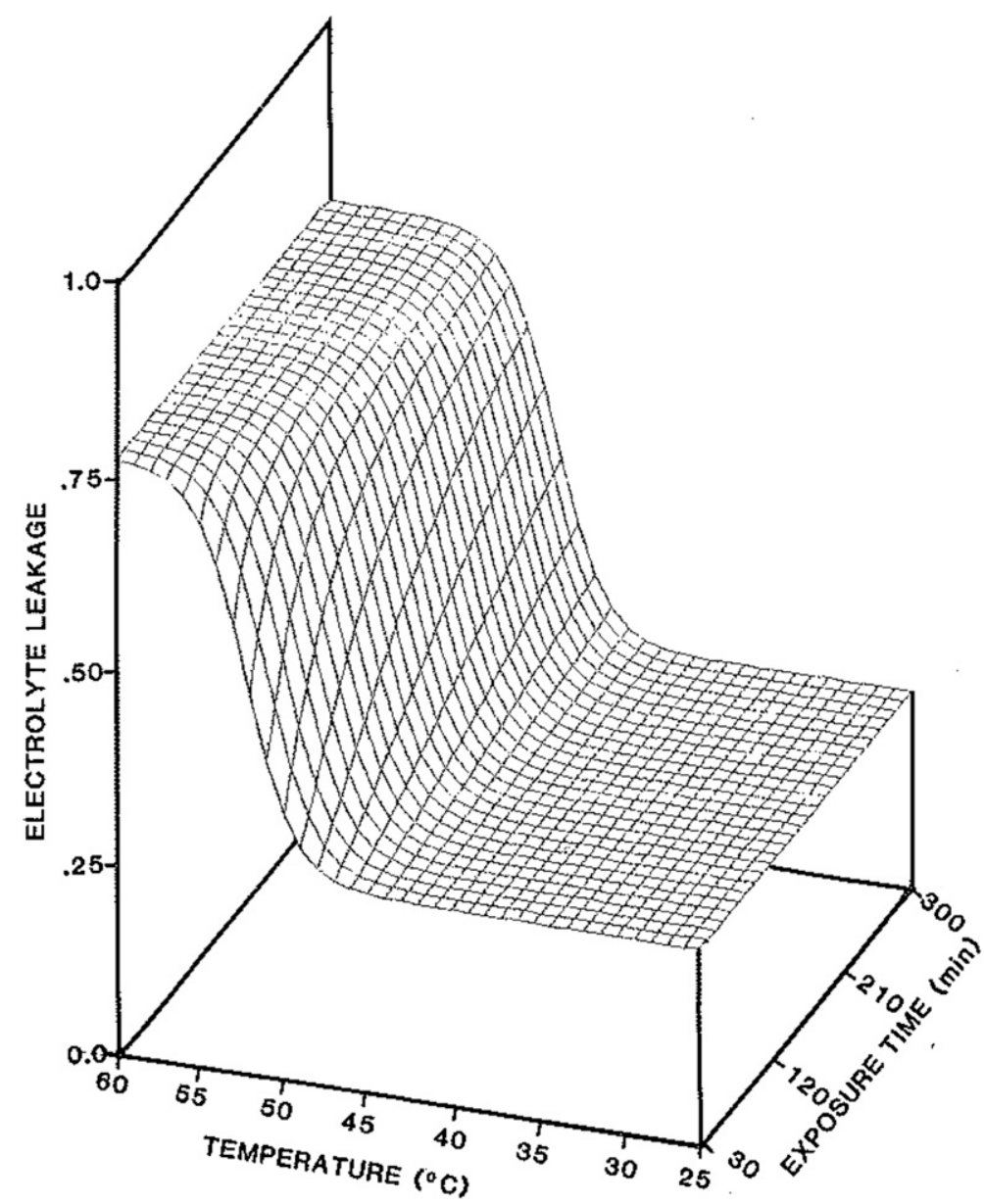

Fig. 1. Graphic presentation of the model describing treatment temperature and exposure time interaction on electrolyte leakage from excised Pittosporum tobira roots. Image taken from Ingram (1985).
$52.6 \pm 0.7{ }^{\circ} \mathrm{C}$, respectively, for a 30 -min exposure and $43.5 \pm 0.8^{\circ} \mathrm{C}$ and $46.7 \pm 0.3{ }^{\circ} \mathrm{C}$ for a 300-min exposure (Ingram, 1986). These data indicate that 'Helleri' holly roots might not be as tolerant of high temperatures and more sensitive to exposure duration than 'Schillings' holly, a plant adapted to more southern, warmer climates (Hume, 1953). Predicted critical exposure duration for Ixora coccinea L. (ixora) root cell membranes were 38 and $221 \mathrm{~min}$ for treatment temperatures of 55 and $50{ }^{\circ} \mathrm{C}$, respectively. Ixora roots exposed to $48{ }^{\circ} \mathrm{C}$ were not injured by a 300-min exposure (Ingram and Ramcharan, 1986).

Research reports suggest that root cell membrane thermostability can change in response to previous exposure of roots to supraoptimal, yet sublethal temperatures. Predicted critical midpoint temperature for Magnolia grandiflora Hort. 'St. Mary' ('St. Mary' magnolia) excised roots for a 30-min exposure was $52.5 \pm 0.9^{\circ} \mathrm{C}$ when the tree root systems were first pretreated for 8 weeks at a RZT of $28^{\circ} \mathrm{C}$ for $6 \mathrm{~h} \cdot \mathrm{d}^{-1}$, but was increased to $54.3 \pm 0.4{ }^{\circ} \mathrm{C}$ or $54.0 \pm 0.4{ }^{\circ} \mathrm{C}$ when tree roots were pretreated for 8 weeks at RZT of 35 or $42{ }^{\circ} \mathrm{C}$, respectively (Martin and Ingram, 1991b).The predicted critical midpoint temperature for Betula nigra L. 'Cully' Heritage ${ }^{\circledR}$ ('Cully' river birch) excised roots for a 30 -min exposure was $54.6 \pm 0.2{ }^{\circ} \mathrm{C}$ when the plants were grown in a pot-in-pot system and $56.5 \pm 0.6{ }^{\circ} \mathrm{C}$ when grown in conventional aboveground containers (Ruter, 1996b). The roots of plants grown in aboveground containers had been exposed to higher temperatures during production than those in the pot-in-pot system.

Protein synthesis decreased and/or protein degradation increased in excised Illicium parviflorum Michx. roots exposed for 15-min to temperatures above $35{ }^{\circ} \mathrm{C}$, which could be expected as cell membranes become more permeable at supraoptimal temperature (Ingram et al., 1986c). Decreased protein content in root tissue with increased temperature was best described by the reciprocal of a sigmoidal curve with a midpoint temperature of $49.1 \pm 2.2{ }^{\circ} \mathrm{C}$, which is perhaps a slightly lower temperature than the predicted critical temperature exposure for loss of cell membrane integrity for a $15-\mathrm{min}$ exposure, $52.0 \pm 1.2^{\circ} \mathrm{C}$.

Therefore, one can conclude that temperatures in the range of 45 to $57^{\circ} \mathrm{C}$ for a 30 -min exposure causes direct injury to root membranes for plants studied, that the critical temperature can be lower for increased exposure durations up to $300 \mathrm{~min}$, but the critical temperature can be raised by previous exposure to supraoptimal, yet sublethal temperatures. However, critical temperature for direct injury does not explain differences in heat tolerance of some cultivars (Sibley et al., 1999) or differences in the same species from different native ranges (Hardin et al., 1999). Such differences in heat tolerance may be explained relative to their response to sublethal RZT over a longer period of time, defined as indirect injury. 


\section{Indirect Injury}

Indirect injury, caused by longer exposure to supraoptimal, yet sublethal temperatures, has been studied from several perspectives. Research has documented impacts on photosynthesis, carbon partitioning, respiration, water relations, hormone synthesis/response, nutrient uptake and utilization, and root diseases. Symptoms of indirect injury may include loss of plant vigor, nutritional disorders, plant architecture modification, increased susceptibility to diseases, and other anomalies in plant developmental characteristics such as flowering and fruiting. Symptoms may not be visible or may go unnoticed when there is no control for comparison.

RZT treatment methods. Paramount to determining the supraoptimal RZT regimens causing indirect injury to plants was the development of techniques to precisely maintain RZT treatments. Researchers have used various types of temperature-controlled water baths into which plant root systems in waterproof containers were suspended (Graves and Dana, 1987; Gur et al., 1972; Wong et al., 1971) or employed hydroponic systems (Geater et al., 1997). Air bath boxes have also been used to apply above-ambient RZT treatments (Johnson and Ingram, 1984; Pellett et al., 1973). Thermostatically controlled light bulbs wrapped with aluminum foil provided convective heat to elevate the temperature and small fans circulated the air in those boxes to increase RZT uniformity (Ingram et al., 1986a; Johnson and Ingram, 1984). This particular system maintained treatment RZT with a variance of 1 to $2{ }^{\circ} \mathrm{C}$ between and within containers.

A solid-state, electronic controller was designed and built to maintain RZT treatments more precisely in specially designed heating tubes (Ingram et al., 1990). The controller used a thermistor feedback mechanism to an amplifier circuit. The tubes were constructed of 7.5 -cm-diameter metal pipe wrapped with electrical heating tape and insulation. RZT treatments from ambient to $50{ }^{\circ} \mathrm{C}$ were maintained with a precision within and between tubes of $\pm 0.9^{\circ} \mathrm{C}$ at $35^{\circ} \mathrm{C}$.

Most of the early work with supraoptimal RZT applied the treatments constantly. Alternative RZT control methods allowed the application of a daily exposure consistent with the observation that supraoptimal RZT were maintained for $\approx 6 \mathrm{~h} \cdot \mathrm{d}^{-1}$ in containergrown plants in outdoor production environments (Ingram, 1981; Martin and Ingram, 1992). Characterization of temperature in containers will be discussed in more detail below.

Growth response. The preponderance of reports indicate that RZT between 35 and $42{ }^{\circ} \mathrm{C}$ cause indirect injury to a wide range of nursery crops as measured in growth parameters and physiological processes. However, the degree of susceptibility differs with species and RZT treatment methods, including length of daily exposure. Berberis thunbergii DC. 'Atropurpurea' ('Atropurpurea' barberry), Pinus eldarica Medu. (Afghan pine) and Buxus mirophylla Seibold and Zucc. (boxwood) were more susceptible to high RZT than pittosporum in an outdoor container production system (Newman and Davies, 1988b). Although there were clonal differences, constant RZT of 30 to $40{ }^{\circ} \mathrm{C}$ for apple (Malus sp. L.) rootstock grown in sand cultures reduced root and shoot growth and leaves were severely damaged by $35^{\circ} \mathrm{C}$ and higher RZT after 10 weeks (Gur et al., 1972, 1976c). Root morphology, root tip elongation, chlorophyll content, and visual quality were also impacted.

Acer rubrum L. (red maple) and Acer $\times$ freemanii E. Murray (Freeman maple) shoot length extension was less when exposed to a constant RZT of $36^{\circ} \mathrm{C}$ after $21 \mathrm{~d}$ compared with treatments of 24 and $30{ }^{\circ} \mathrm{C}$ (Graves et al., 1989), but sensitivity differed between cultivars (Wilkins et al., 1995). Gleditsia triacanthos var. inermis Willd. (honey locust) shoot extension, leaf area, root:shoot ratio, and root and shoot dry weights were less in a constant $21-\mathrm{d} 34{ }^{\circ} \mathrm{C} \mathrm{RZT}$ treatment compared with a $24{ }^{\circ} \mathrm{C}$ treatment (Graves et al., 1991).

Shoot and/or root growth reductions from RZT treatments of 40 to $42{ }^{\circ} \mathrm{C}$ for $6 \mathrm{~h} \cdot \mathrm{d}^{-1}$ have been reported for pittosporum, 'Carrizo' citrange [Citrus sinensis L. (Osbeck.) $\times$ Poncirus trifoliate L. (Raf.)] seedlings, Dracaena marginata L. 'Tricolor' ('Tricolor' dracaena) 'Grande Naine' banana (Musa sp. L., AAA Group), Ilex $\times$ attenuata Ashe 'East Palatka' ('East Palatka' holly), Ulmus parvifolia Jacq. 'Drake' ('Drake' elm), and 'St. Mary' magnolia but not for ixora (Ingram et al., 1986a, 1986b; Johnson and Ingram, 1984; Martin and Ingram, 1991b).

It has been well documented that supraoptimal RZT below those causing direct injury alter the root-to-shoot ratio. In most cases, the root:shoot decreased at RZT of 35 to $40{ }^{\circ} \mathrm{C}$ with greater reductions in root growth compared with shoot growth at these supraoptimal RZT. Root systems of a range of plants exposed to supraoptimal RZT were generally smaller (less dry weight), darker in color, exhibited apical tip necrosis, were less sucullent, had a water-soaked appearance and/or had a modified branching pattern compared with plants grown at near optimal RZT (Barr and Pellett, 1972; Martin and Ingram, 1991a; Ramcharan et al., 1995).

Plant architecture can also be impacted by sublethal, supraoptimal RZT. For example, increaesed spur-type brachlets with many small leaves in apple trees (Gur et al., 1976b) and decreased branching and increased height in citrus have been observed (Ingram et al., 1986b). Supraoptimal RZT can also change growth habit even without impacting overall growth. Plant height, shoot dry weight, leaf length, and leaf number of 'Grand Naine' banana were not impacted by RZT up to $43{ }^{\circ} \mathrm{C}$ for $6 \mathrm{~h} \cdot \mathrm{d}^{-1}$, but leaf width and leaf area were smaller in the 38 and $43^{\circ} \mathrm{C}$ RZT treatments compared with 28 and $33^{\circ} \mathrm{C}$ treatments (Ramcharan et al., 1995). The authors postulated that the differences in leaf characteristics could have been a hormone-mediated response due to the death or injury of root tips at high RZT.

Growth anomalies in the epidermis of secondary and fibrous roots were reported in 'St Mary' magnolia exposed to 38 and $42{ }^{\circ} \mathrm{C}$ RZT treatments, but not to 30 and $34{ }^{\circ} \mathrm{C}$ treatments (Martin et al., 1991b). It appears these anomalies were expressions of modifications in root plasma membranes as shown in scanning electron micrographs (Fig. 2). These RZT treatments were below those predicted to cause direct injury and the pattern of woundcallus morphogenesis would indicate that it occurred at temperatures below those causing death of magnolia root tissues.

Field observations indicate that plants can recover when a portion of their root systems is stressed, injured, or killed. Seasonal change in the incidence of direct solar radiation on various sides of a container results in death of roots in one season and a regrowth of roots in that portion of the substrate in subsequent seasons due to change in the angle of incidence of solar radiation. Unpublished observations by the authors also indicate that regrowth occurs primarily from more mature roots.

There is evidence that heat-acclimated plants might withstand higher RZT before sustaining indirect injury than nonacclimated plants. Shoot and root dry weights of 'St. Mary' magnolia after a 30 or $38^{\circ} \mathrm{C}, 6 \mathrm{~h} \cdot \mathrm{d}^{-1}$ RZT treatments for 8 weeks and transplanted into larger containers for 16 weeks were greater than plants grown in a $42{ }^{\circ} \mathrm{C}$ RZT treatment, indicating that magnolia could overcome the impact of exposure to a RZT treatment of $38{ }^{\circ} \mathrm{C}$ but not to a $42{ }^{\circ} \mathrm{C}$ RZT treatment (Martin and Ingram, 1991b). Acclimation in plants to withstand higher temperatures is a complex phenomenon involving such responses as heat stress proteins, membrane lipid fatty acid modifications and multiple signaling pathways (Iba, 2002; Kotak et al., 2007; Murakami et al., 2000). Sublethal, yet supraoptimal RZT can also change cell membrane integrity. High RZT up to $35{ }^{\circ} \mathrm{C}$ induced severe lipid oxidation in Agrostis palustris Huds. (creeping bentgrass) compared with high air temperature (Huang et al., 2001). Higher malondialdehyde content in this grass indicated that membrane lipid peroxidation had occurred at the higher RZT. Reducing RZT alleviated some of the detrimental effects of oxidative stress.

From these reports, it can be concluded that sublethal yet supraoptimal RZT of 38 to $42{ }^{\circ} \mathrm{C}$ reduce dry weight accumulation in shoots and/or roots and change the morphology of roots and shoots. The degree of impact and the nature of that impact appears to vary with plant species and by cultivar in some cases, but in most plants studied the critical RZT negatively impacting growth were 38 to $40{ }^{\circ} \mathrm{C}$ for $6 \mathrm{~h} \cdot \mathrm{d}^{-1}$. Preconditioning plants to elevated RZT can result in a greater tolerance of some plants to RZT in this range

Photosynthesis. Supraoptimal RZT have been shown to significantly affect the rate of photosynthesis. Reduction can be caused by heat-induced water stress, which either 

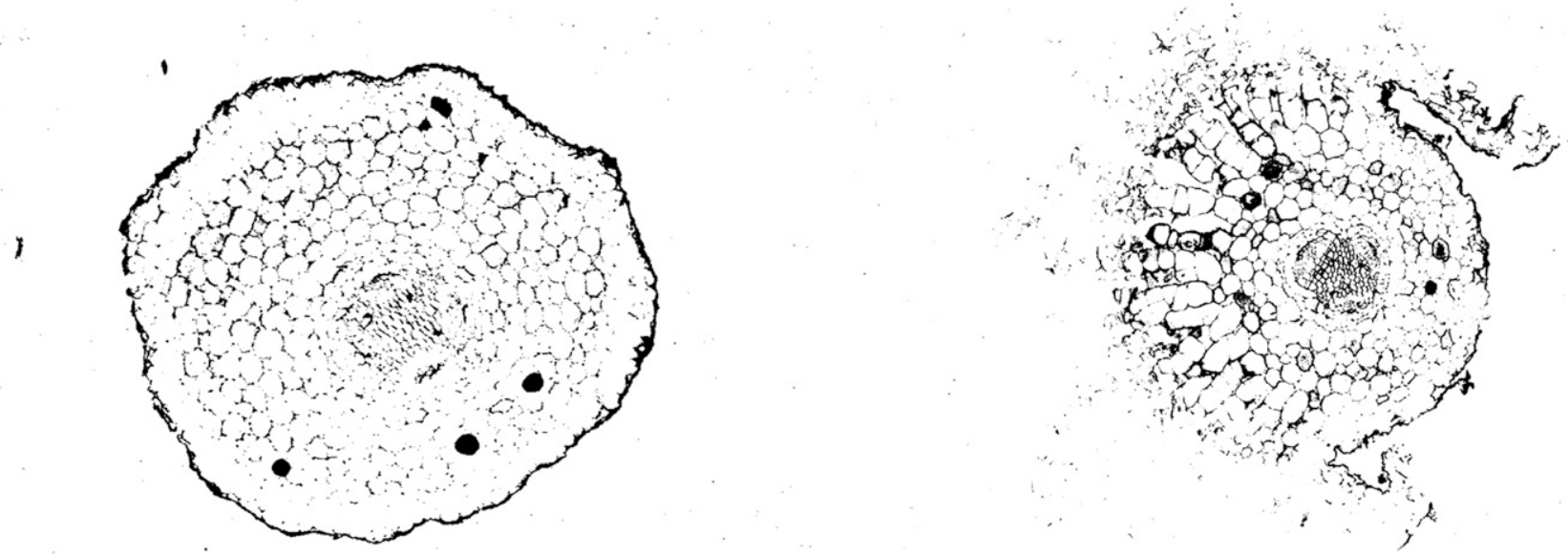

Fig. 2. Effect of root-zone temperatures on root morphology of Magnolia grandiflora 'St Mary'. Left $=$ cross section of nonaffected fibrous root. Right $=$ cross section of fibrous root showing a break in the epidermal layer and proliferation of undifferentiated parenchyma cells induced by 42 or $38^{\circ} \mathrm{C}$ RZT treatments for $6 \mathrm{~h} \cdot \mathrm{d}^{-1}$. Images taken from Martin et al. (1991b).

results in closing the stomata or injury to the photosynthetic process due to desiccation. Supraoptimal RZT have also been reported to injure the photosynthetic apparatus directly and independent of water stress.

After 4 months of treatment, rates of photosynthesis, transpiration, and leaf water potential decreased in one-year-old M.2 apple rootstock trees with constant RZT treatments of 22,29 , and $36^{\circ} \mathrm{C}$ (Gur et al., 1976a). Potassium (K) and chlorophyll contents of leaves were also decreased by increasing RZT from 29 to $36{ }^{\circ} \mathrm{C}$. Leaf chlorophyll content of Freeman maple cultivars was reduced by a constant RZT of $34{ }^{\circ} \mathrm{C}$ compared with $28{ }^{\circ} \mathrm{C}$ for $32 \mathrm{~d}$ (Wilkins et al., 1995). Air temperature and RZT in the range of 15 to $35^{\circ} \mathrm{C}$ influenced $\mathrm{CO}_{2}$ assimilation in Rubus idaeus L. 'Heritage', with maximum rates occurring at an air temperature/RZT of $17 / 25^{\circ} \mathrm{C}$ (Percival et al., 1996). High RZT in Prunus mira Koehne (smoothpit peach) seedlings decreased leaf water content and decreased photosynthesis (Hao et al., 2012).

Decreased photosynthesis can be attributed to induced and/or concurrent water stress caused by supraoptimal RZT. Time trend analysis for 'East Palatka' holly and 'Drake' elm leaf carbon exchange rates and $g_{\mathrm{S}}$ revealed reductions at $42{ }^{\circ} \mathrm{C}$ RZT compared with 35 and $28^{\circ} \mathrm{C}$ for $6 \mathrm{~h} \cdot \mathrm{d}^{-1}$ (Martin et al., 1989). Photosynthesis rate was reduced by a $40{ }^{\circ} \mathrm{C}$ RZT treatment for 7 months in pittosporum compared with RZT of 28 and $30{ }^{\circ} \mathrm{C}$ (Johnson and Ingram, 1984).

Photosynthesis in Ilex crenata Thunb. 'Rotundifolia' ('Rotundifolia' holly) was decreased by RZT treatments of 32,36 , and $40{ }^{\circ} \mathrm{C}$ for $6 \mathrm{~h} \cdot \mathrm{d}^{-1}$ for $7 \mathrm{~d}$ compared with a RZT of $28^{\circ} \mathrm{C}$ (Foster et al., 1991). The decreased photosynthetic rates were not due to increased stomatal resistance. In a subsequent study, photosynthesis in 'Rotundifolia' holly was reduced after 3 weeks by RZT treatments of 38 and $42{ }^{\circ} \mathrm{C}$ compared with 30 and $34{ }^{\circ} \mathrm{C}$ (Ruter and Ingram, 1992). Chlorophyll and carotenoid levels decreased while leaf soluble protein levels increased as RZT increased. Ribulose-1,5-bisphosphate carboxylase/oxygenase ( $\mathrm{RuBisCO}$ ) activity per unit protein and per unit chlorophyll responded quadratically with the highest level from a $34{ }^{\circ} \mathrm{C}$ RZT, while RuBisCO activity per unit fresh weight increased linearly in response to increasing RZT. It was suggested that 'Rotundifolia' holly was capable of altering its metabolism or redistributing available assimilates to maintain $\mathrm{CO}_{2}$ assimilation rates in response to increasing RZT.

Supraoptimal RZT have been show to affect the diurnal fluctuation in leaf carbon assimilation in 'Grand Naine' banana and ixora, although the affect differed between greenhouse and growth room environments (Ramcharan et al., 1991). In a growth chamber, a RZT treatment of $43{ }^{\circ} \mathrm{C}$ that started at 10:00 AM resulted in a maximum assimilation around midday for banana, but not until afternoon in ixora. Although the impact of 33 and $38{ }^{\circ} \mathrm{C}$ RZT on measured processes differed somewhat between environments, the $43{ }^{\circ} \mathrm{C}$ RZT treatment decreased assimilation and leaf conductance in both environments.

Therefore, RZT in the range of 32 to $40^{\circ} \mathrm{C}$ are critical in terms of photosynthetic rate. Reduction in photosynthesis from high RZT can be associated with heat-induced water stress, reduction in chlorophyll, carotenoid or $\mathrm{K}$ availability, and/or decreased RuBisCO activity.

Carbon partitioning. Supraoptimal RZT have been shown to alter carbon partitioning.
Absolute concentration of sugars and starch in shoots and roots of 'Grand Naine' banana, ixora, 'Carizzo' citrange, and 'Tricolor' dracaena did not differ with RZT but the ratio of sugars to starch in roots was reduced in ixora and increased in banana by a $6 \mathrm{~h} \cdot \mathrm{d}^{-1} 40^{\circ} \mathrm{C}$ RZT treatment for $90 \mathrm{~d}$ compared with 28 and $34{ }^{\circ} \mathrm{C}$ (Ingram et al., 1986b).

A portion of the root system of plants grown at RZT near optimal may be able to compensate somewhat for some portion of the root system being exposed to supraoptimal RZT. In a system using split root systems, growth analysis data demonstrated that a RZT of $38{ }^{\circ} \mathrm{C}$ for the whole root system of 'Rotundifolia' holly constituted an upper threshold for several growth and physiological characteristics (Ruter and Ingram, 1990). A portion of the root system grown at or near the optimum temperature $\left(30^{\circ} \mathrm{C}\right)$ could compensate, in terms of shoot growth over a 3-week period, for the adverse effects of exposing part of the root system to RZT treatments up to $38^{\circ} \mathrm{C}$, but not $42{ }^{\circ} \mathrm{C}$. Supraoptimal RZT did not affect short-term photosynthetic rates, but altered photosynthate partitioning to various stem and root sinks. When one portion of the root system was exposed to a $30^{\circ} \mathrm{C}$ RZT, the percent of recovered current photosynthate in the stem decreased with increasing RZT from 34 to $42{ }^{\circ} \mathrm{C}$ in the other portion of the roots. It appears that roots depend on a supply of current assimilates available in a soluble form from the stem at elevated RZT. Measurement of currently assimilated photosynthate exudate in the substrate due to a $42{ }^{\circ} \mathrm{C}$ RZT treatment reflects the degree of membrane damage predicted at that temperature (Ruter and Ingram, 1991).

Again, the critical RZT for physiological process such as carbon partitioning are $38^{\circ} \mathrm{C}$ 
or above. Interestedly, a portion of the root system at near optimum RZT can compensation for a portion of the root system exposed to higher RZT. This may validate field observations of seasonal changes in the region of containers in which roots are injured by high RZT with minimal observable impact on shoot growth.

Respiration. Respiration rates are also influenced by supraoptimal RZT. Root respiration in pittosporum was increased by a $6 \mathrm{~h} \cdot \mathrm{d}^{-1} \mathrm{RZT}$ of $40^{\circ} \mathrm{C}$ for 7 months compared with a RZT of 27 and $30{ }^{\circ} \mathrm{C}$ (Johnson and Ingram, 1984). Total root carbohydrate levels were also reduced by that treatment.

Root respiration was shown to increase in 'Rotundifolia' holly with increasing RZT of $28,32,36$, and $40{ }^{\circ} \mathrm{C}$ after $7 \mathrm{~d}$ of $6 \mathrm{~h} \cdot \mathrm{d}^{-1}$ treatments (Foster et al., 1991). Supraoptimal RZT impact the partitioning of assimilated carbon into soluble and insoluble fractions, which are related to the magnitude of root respiration (Ruter and Ingram, 1990). When a portion of the roots system was exposed to $38{ }^{\circ} \mathrm{C}$, respiration rate increased in that portion of the root system as well as the rest of the root system exposed to a near optimal RZT of $30^{\circ} \mathrm{C}$.

Gur reported increased aerobic respiration in apple roots exposed to constant $35^{\circ} \mathrm{C}$ and a shift to anaerobic respiration with exposure to $40{ }^{\circ} \mathrm{C}$ (Gur et al., 1972). Apple rootstock showed maximum $\mathrm{O}_{2}$ consumption, $\mathrm{CO}_{2}$ evolution, and respiratory quotient of the roots at constant RZT of $35^{\circ} \mathrm{C}$. Supraoptimal RZT also lowered malic acid content in the roots and increased acetaldehyde content of both roots and shoots.

Respiration rates of 'Rotundifolia' holly roots excised from plants grown for 3 weeks with RZT of $30,34,38$, or $42{ }^{\circ} \mathrm{C}$ decreased linearly with increasing RZT treatment when the buffer solution was maintained at $25{ }^{\circ} \mathrm{C}$ (Ruter and Ingram, 1991). Respiration in roots from plants receiving a $30{ }^{\circ} \mathrm{C}$ RZT treatment was maximal with the buffer solution at $34{ }^{\circ} \mathrm{C}$ and decreased to a minimum at $46{ }^{\circ} \mathrm{C}$. Above $46{ }^{\circ} \mathrm{C}$, a presumably extramitochondrial stimulation of $\mathrm{O}_{2}$ consumption occurred.

Respiration rate in tomato (Solanum lycopersicum L.) roots also increased during the first $8 \mathrm{~d}$ of exposure to a constant $36^{\circ} \mathrm{C}$ RZT then decreased significantly for the next $10 \mathrm{~d}$ (Klock et al., 1997). It was postulated that such a decrease in respiration over time could be due to lack of respirable substrates and/or inactivation of respiratory enzymes at that RZT. Tolerance of Agrostis scabra L. (rough bentgrass) to supraoptimal RZT was associated with short-term (60 $\mathrm{min})$ and long-term (7-28 d) acclimation in the respiratory system. Increased root respiration to compensate for increased carbon demand during acclimating temperature exposure may have resulted in extended root survival at high RZT (Rachmilevitch et al., 2008).

Unlike carbon partitioning, root respiration does not appear to be impacted by having another portion of the root system at near optimum temperature. However, the respiration rate in roots appeared to have increased from exposure to RZT up to 40 to $42{ }^{\circ} \mathrm{C}$. Respiration decreased in roots exposed to temperatures above this range, presumably due to disruption of the respiratory pathway components or the lack of respirable substrate.

Heat-induced water stress. Supraoptimal RZT can induce increased water use or water stress in plants (Barr and Pellett, 1972). A primary consequence of early water stress induced by elevated RZT in many plants is a closure of stomata, and therefore, increased stomatal resistance, decreased water potential, and reduced photosynthesis due to lack of $\mathrm{CO}_{2}$ substrate in the leaf or damage to the photosynthesis mechanism. However, the response differed by species.

Root hydraulic conductivity increased in 'Atropurpurea' barberry compared with boxwood at a constant 40 and $45{ }^{\circ} \mathrm{C}$ RZT, indicating less $\mathrm{RZT}$-induced resistance in 'Atropurpurea' barberry roots (Newman and Davies, 1988a). Predawn xylem water potential increased initially at RZT of 40 and $45^{\circ} \mathrm{C}$ but then decreased over a 5-d period. Stomatal conductance and evapotranspiration were reduced by these RZT treatments as well.

Five weeks of constant RZT treatments of 30 and $36{ }^{\circ} \mathrm{C}$ in red maple increased leaf diffusive resistance 5-fold and decreased shoot water potential (Graves et al., 1989). It was suggested that turgor in these plants was maintained by increased solute concentration in leaves of plants held at a $36{ }^{\circ} \mathrm{C}$ RZT. A constant $34{ }^{\circ} \mathrm{C}$ RZT decreased transpiration in red maple and Freeman maple cultivars by $25 \%$ to $89 \%$ compared with a 28 ${ }^{\circ} \mathrm{C}$ RZT (Wilkins et al., 1995).

Honey locust seedlings water stressed by osomotic potential adjustment with polyethylene glycol were relatively insensitive to RZT up to $35^{\circ} \mathrm{C}$ (Graves and Wilkins, 1991). In another study, honey locust grown at a constant RZT of $34{ }^{\circ} \mathrm{C}$ had a lowered mean transpiration rate and water flux through the root system but increased shoot extension compared with a constant $24^{\circ} \mathrm{C}$ RZT (Graves et al., 1991). Water content increased in apple roots and decreased in leaves with constant supraoptimal RZT up to $36{ }^{\circ} \mathrm{C}$ (Gur et al., 1976a). Increased water content in the substrate may not alleviate RZT-induced water stress (Ramcharan et al., 1995).

Research has shown that there is a lot of variation in the critical RZT for heat-induced water stress in plants, but critical RZT are in the range of 30 to $40^{\circ} \mathrm{C}$. This variability may be due to differences in treatment methods and/or plant species.

Nutrition. The uptake of nutrients has been shown to be impacted by supraoptimal RZT as measured by tissue content. As one would expect, this differs with species and their relative RZT tolerance, as well as with nutrient ion. Roots damaged by supraoptimal RZT may not have the energy or functional mechanisms to uptake nutrients and the distribution of nutrients taken up in these stressed plants have been shown to be affected by RZT treatments.
Potassium (K) leaf content has been shown to be reduced by supraoptimal RZT (Barr and Pellett, 1972). Reduced leaf K content of apple grown at a constant $30{ }^{\circ} \mathrm{C}$ RZT could be overcome by high $\mathrm{K}$ concentrations in nutrient solutions in sand culture but not at a $35^{\circ} \mathrm{C} \mathrm{RZT} \mathrm{(Gur} \mathrm{et} \mathrm{al.,} \mathrm{1979;} \mathrm{Gur}$ and Shulman, 1971). Foliar sprays of potassium nitrate resulted in a similar response as increased $\mathrm{K}$ in the nutrient solution (Gur et al., 1976b). RZT of 25 to $30{ }^{\circ} \mathrm{C}$, depending upon rootstock clone, decreased $\mathrm{K}$ and zinc (Zn) content of all parts of apple plants with an corresponding increase in sodium $(\mathrm{Na})$, calcium $(\mathrm{Ca})$, and magnesium $(\mathrm{Mg})$ contents in the roots, indicating RZT-induced change in ion uptake and/or translocation.

Nitrogen $(\mathrm{N})$ leaf content of pittosporum grown at $40{ }^{\circ} \mathrm{C} \mathrm{RZT} \mathrm{for} 6 \mathrm{~h} \cdot \mathrm{d}^{-1}$ for 7 months was greater than in plants at 27 or $30{ }^{\circ} \mathrm{C}$ (Johnson and Ingram, 1984). Greater $\mathrm{N}$ content could have related to the decreased dry weight accumulation at this RZT. Higher $\mathrm{N}$ leaf tissue levels in tropical fruits from a $32{ }^{\circ} \mathrm{C}$ RZT treatments than at lower temperatures were reported (Yusof et al., 1969). K, iron (Fe), and $\mathrm{Zn}$ contents were lower than when grown at RZT of 27 and $32{ }^{\circ} \mathrm{C}$ (Johnson and Ingram, 1984). Phosphorus (P), $\mathrm{Mg}$, and $\mathrm{Ca}$ leaf contents were unaffected by RZT treatments.

'Rotundifolia' holly grown in sand culture with varying levels of $\mathrm{N}$ fertilization accumulated less $\mathrm{N}$ in roots and shoots with increased RZT from 28 to $40{ }^{\circ} \mathrm{C}$ for $6 \mathrm{~h} \cdot \mathrm{d}^{-1}$ (Yeager et al., 1991). Increased $\mathrm{N}$ fertilization rates up to $225 \mathrm{mg} \mathrm{N} / \mathrm{L}$ did not overcome plant growth reduction due to supraoptimal RZT. For Photinia $\times$ fraseri Dress, a species thought to be more heat tolerant than 'Rotundifolia' holly, shoot and root dry weight gain was greatest and $\mathrm{N}$ accumulation per dry weight was least at $34{ }^{\circ} \mathrm{C}$ for $6 \mathrm{~h} \cdot \mathrm{d}^{-1} \mathrm{com}$ pared with 28 and $40{ }^{\circ} \mathrm{C}$ (Harrison et al., 1988). Increased growth could have diluted the $\mathrm{N}$ accumulation per dry weight, indicating $\mathrm{N}$ uptake may have not limited growth. Net uptake of nitrate in two red maple cultivars was increased by RZT up to $34^{\circ} \mathrm{C}$ but RZT approaching those known to reduce growth were not included in the study (Adam et al., 2003). The rate of $\mathrm{N}$ mineralization in container substrates composed of organic composts was generally greater at a supraoptimal RZT of $45^{\circ} \mathrm{C}$ (Kraus et al., 2000). Therefore, supraoptimal RZT might result in increased availability of $\mathrm{N}$ in substrates containing organic compost, presumably due to increased mineralization.

The $\mathrm{P}$ concentrations in shoots have been shown to decrease over time at a RZT of $36^{\circ} \mathrm{C}$ but not at $25^{\circ} \mathrm{C}$ (Barr and Pellett, 1972; Klock et al., 1997). The higher RZT also decreased shoot growth, and therefore, the demand for $\mathrm{P}$, along with decreased root respiration, likely contributed to the decreased $\mathrm{P}$ shoot concentration. Manganese $(\mathrm{Mn})$ content in honey locust decreased with increasing RZT from 24 to $36^{\circ} \mathrm{C}$ but growth, $\mathrm{P}, \mathrm{Zn}$, and $\mathrm{Mn}$ contents were not changed by continuous exposure in a hydroponic system (Klock et al., 1996). 
Although somewhat variable, nutrient uptake is retarded by RZT of 36 to $40{ }^{\circ} \mathrm{C}$. The ability of plants to activity uptake and/or translocate nutrients by these RZT have been implicated.

Hormones. Supraoptimal RZT have been reported to impact the production of hormones, and possibly the movement of hormones and/or plant response to endogenous concentrations. Decreased cytokinin level were reported in apple due to supraoptimal RZT and could explain the reduced number of nodes formed at these elevated RZT (Gur et al., 1976b). A reduction in apical shoot growth due to supraoptimal RZT was postulated to decrease apical dominance. RZT of $35^{\circ} \mathrm{C}$ and higher decreased leaf size, quality, and number and were associated with reduced cytokinins in both roots and leaves of apple grown in a sand culture which was moderated by application of kinetin and benzyladenine to the leaves (Gur et al., 1972).

High RZT triggered accumulation of ABA in leaves of smoothpit peach seedlings which in turn may have enhanced the thermotolerance of photosystem II (PSII), at least partially through changes in leaf water status (Hao et al., 2012). Exogenous application of ABA significantly alleviated the damage of the primary photochemistry of PSII caused by high RZT. Shoot injury in creeping bentgrass caused by high RZT up to $35^{\circ} \mathrm{C}$ was associated with the inhibition of cytokinin production and the induction of oxidative stress (Wang et al., 2003). Cytokinin levels in the cool season grass was reported to be highly sensitive to elevated RZT (Liu and Huang, 2005).

It is apparent that RZT above $35^{\circ} \mathrm{C}$ can reduce cytokinin levels and increase $\mathrm{ABA}$ in some plants. The addition of exogenously applied cytokinins can overcome some of that reduction in synthesis or activity of endogenous hormones, but more clarity of the system is needed.

Mycorrhizae. Mycorrhizal fungi colonization of roots has impacted, at least in the short-term, measureable stress response to supraoptimal RZT in some plants. "Atropurpurea' barberry, boxwood and 'Wheeler' pittosporum colonized with arbuscular mycorrhizal fungi Glomus etunicatum Baker and Gerd. and G. fasciculatum Thax. sensu Gerd. showed less stress by supraoptimal RZT initially (1-2 d), but not later in the study (Newman and Davies, 1988a). 'Wheeler's Dwarf' pittosporum colonized with mycorrhizal fungi ( $G$. etunicatus and G. fasciculatum) had increased shoot growth compared with noninoculated plants and increased root growth in the containers on western and eastern bed exposures (Newman and Davies, 1988b). Mycorrihizal fungi colonization did not impact growth of 'Atropurpurea' barberry, which proved to be more sensitive to supraoptimal RZT than pittosporum or boxwood in the project.

Root disease. Supraoptimal RZT have been shown to predispose plant roots to soil-borne diseases. There was relatively little disease developed on Dendranthema xgrandiflorum (Ramat.) Kiam. 'Paragon' plants exposed to 25 or $35^{\circ} \mathrm{C} \mathrm{RZT} \mathrm{in} \mathrm{various}$ systems and inoculated with Phytophthora cryptogea Pethyb. \& Laff., but infection was severe in roots heated to $40{ }^{\circ} \mathrm{C}$ (MacDonald, 1991). Visual assessment of root discoloration and culturing of randomly selected root pieces showed that Hibiscus rosa-sinensis L. exposed to 40 or $50{ }^{\circ} \mathrm{C}$ RZT had a significantly higher incidence of infection after inoculation with zoospores of Phytophthora parasitica Dastur than those exposed to 20 or $30{ }^{\circ} \mathrm{C}$ (Lyles et al., 1992).

Supraoptimal RZT causing indirect injury to plants do so by impacting physiological and biochemical processes such as photosynthesis, respiration, carbon partitioning, hormone synthesis and/or activity and nutrient uptake and utilization, as well as predispose plants to disease. Over this range of processes and a wide array of plant materials, it can be concluded that critical RZT for indirect injury are generally in the range of 38 to $40{ }^{\circ} \mathrm{C}$ and should be the target threshold for efforts to reduce temperatures in production containers.

\section{Heat Flow in Container Substrates and Implications for Production Systems}

Understanding the parameters involved in heat flow in containers is paramount to modifying container production systems to reduce supraoptimal RZT. Reported temperature extremes have varied with the exact location of temperature sensors in the substrate, container spacing, container size, time of day, season of year, geographic location, and growth substrate as well as the material and color of containers. RZT in fully exposed containers generally exceed $40{ }^{\circ} \mathrm{C}$ for six or more hours daily. Most research as described above shows that 38 to $40{ }^{\circ} \mathrm{C}$ RZT for $6 \mathrm{~h} \cdot \mathrm{d}^{-1}$ caused indirect injury to physiological processes of test plants and a short exposure to 46 to $52{ }^{\circ} \mathrm{C}$ disrupts cell membranes. Therefore, container system modifications to reduce RZT below critical levels should target reduction to these thresholds.

Outdoor container production systems generally entail plants growing aboveground in containers in full sun or in shade structures. The containers are placed on beds covered most often with a polypropylene fabric or gravel. They are generally grown at a close spacing for some period of time before being spaced to give adequate space for the shoot development and required pruning and maintenance. The growth substrate in outdoor container production systems is comprised primarily of composted organic residues such as pine bark or other wood industry byproducts. Sand or small gravel is sometimes incorporated to add weight to stabilize the containers. Heat energy enters the container from direct and reflected solar radiation and results in daytime RZT significantly above ambient. Containers act as solar collectors in the system, as do the surrounding surfaces. Heat is transferred within the container primarily through conduction and to the external environment via convection, long wave radiation, and the latent heat of vaporization. The containers have a high surface area to volume ratio, especially in smaller nursery production containers, which results in rapid RZT fluctuations and extremes. Many reports of RZT in exposed containers approaching or exceeding $50{ }^{\circ} \mathrm{C}$ have been published (Fretz, 1971, 1972; Haun and Fulmer, 1971; Ingram, 1981; Self and Ward, 1956; Young and Hammett, 1980).

Simulation modeling has been a valuable tool for understanding the interactive dynamics of heat flow within a container/substrate system and with the surrounding environment. Thermal energy exchanges at the system's boundaries are a function of radiation, convection, evaporation and conduction energy fluxes (Martin and Ingram, 1992). Model parameters included: the incidence of solar radiation throughout the day, the reflectivity of the container surface (albedo), the thermal conductivity of the container, heat exchange between the container sidewall and the growth substrate, the thermal conductivity of the growth substrate over a range of moisture content, heat exchange between the container sidewall and the surrounding environment, the heat exchange between the substrate surface and the surrounding environment, and heat exchange between the container sidewall and the substrate.

Compared with net radiation and convection, conduction and evaporation have little effect on heat exchange at the substrate's top surface during sunlight hours (Martin and Ingram, 1992). The vast majority of thermal energy to the container comes from direct solar radiation on the exposed container wall. The reported fact that ambient air temperature has a relatively small impact on midsummer RZT is intuitive given the fact that reported RZT are much higher than the ambient air temperature. Convective cooling for containers with solid, plastic sidewalls was ineffective and wind speed and direction would have minimal impact on RZT in that model. However, the influence of evaporative cooling in containers with porous sidewalls was not modeled.

RZT of container substrate adjacent to the eastern container wall increase dramatically as soon as solar radiation strikes the container wall in the morning. The maximum RZT migrate to various regions of the container substrate throughout the day with maximum daily RZT in midsummer occurring in the western quadrant in southern United States (Fretz, 1972; Ingram, 1981; Keever and Cobb, 1984a; Martin and Ingram, 1992, 1993). The container quadrant receiving the most intense solar radiation differs not only with time of day but also time of year. The declination angle of the sun from the horizon and solar altitude are lowest during midwinter and has been observed to injure roots in the southern quadrant of the container in Florida, United States (latitude 29.6N). Supraoptimal RZT at latitude $43.14 \mathrm{~N}$ were most frequent between late August and early October, despite cool air temperatures, as 
a result of clear, sunny days and the low declination angle of the sun (Neal, 2010).

The northern quadrant of containers receives little direct solar radiation during a production cycle unless containers are moved and reoriented. Roots may recover from exposure in one quadrant just to be injured in another quadrant by extreme RZT as the season changes. There is also potential for root injury in container-grown plants that are moved from the container nursery to a landscape site or a retail establishment where they are repositioned and the northern side of the container exposed to direct solar radiation for even a short period of time.

RZT in container-grown plants can also be affected by container and substrate properties and water management. Production protocols aimed at reducing incidence of solar radiation on container walls can also impact RZT. These topics will be addressed in subsequent sections.

Container properties. Container color, and therefore container albedo, impacts RZT. White, silver, green, and yellow colored containers or containers with a reflective surface have a higher albedo, absorb less direct solar radiation, and result in RZT that are as much as 5 to $10^{\circ} \mathrm{C}$ lower than in black containers (Fretz, 1971; Haun and Fulmer, 1971; Ingram, 1981; Markham et al., 2011). The maximum daily RZT were measured at $\approx 2.5 \mathrm{~cm}$ from the sidewall and midway the 3-L container height.

Container material also impacts the transfer of heat at the container/environment interface but generally less than container color or reflectivity. Thick paper containers or fiber pots absorb and conduct less radiant energy (Nambuthiri et al., 2015b; Ruter, 1995, 1996a, 1997, 1999, 2000a, 2000b, 2000c, 2000d, 2001) than plastic or metal containers, and have been shown to reduce RZT and increase growth in some plants. Maximum RZT in fiber containers were often as much as $10{ }^{\circ} \mathrm{C}$ lower than conventional black plastic containers and were correlated to increased dry mass of shoots and roots in garden mums, Hemerocallis L. 'Aztec Gold' and 'Stella de Oro', Leucothoe fontanesiana (Steudel) Sleumer 'Rainbow', Pieris japonica Thunb. 'Mt. Fire', Syringa L. 'Angel White' and 'Lavender Lady', Viburnum plicatum Thunb. var. tomentosum 'Shasta', Ilex $\times$ meservae $\mathrm{S}$. Y.Hu 'Blue Princess', Chamaecyparis obtusa Siebold \& Zucc. 'Crippsii', Juniperus chinensis L. 'Gold Star', and Thuja occidentalis L. 'Little Giant'. Increased dry weights in these plants grown in fiber compared with black plastic containers ranged from $10 \%$ to $204 \%$. River birch growth and quality were less and temperature extremes and fluctuations were greater in standard black containers compared with containers comprised of porous black fabric, nonporous white fabric or two types of black plastic mesh (Papineau and Neal, 2015).

Evaporative cooling in containers made of a porous material such as a fired clay or peat result in lower RZT, assuming adequate water is present to evaporate (Jones, 1931;
Nambuthiri et al., 2015a). Mesh container walls also increased the efficiency of heat loss from substrates to the surrounding environment due to increased evaporation, but water demand increased (Verma, 1979) as is true for containers with slits or openings in an otherwise solid sidewall. Porous containers allow oxygen exchange through the sidewall (Ruter, 2001). This exchange does not occur with solid plastic containers, and therefore, plants which are sensitive to low substrate oxygen levels suffer. High RZT also increase the demand for oxygen since root respiration increases with RZT up to temperatures causing damage to the respiratory process. The combination of high RZT and low substrate oxygen levels can decrease plant growth (Letey et al., 1963; Mathers et al., 2007).

Maximum daily RZT at the center of container substrates is generally lower and occurs later in the day as container volume increases (Martin and Ingram, 1993). This appears to be a direct function of the distance that heat energy must be transferred through the substrate. Growth of young 'St. Mary' magnolia was generally increased with increased container volume because temperature patterns at the center location differed as a function of container volume. The mean maximum RZT at the center of the container were 4.8 and $6.3^{\circ} \mathrm{C}$ lower for 57 -L containers than for 27 or 10 -L containers, respectively. These results suggested that the time required for young magnolia trees to attain marketable size when containers are spaced apart might be reduced by production schedules that shift trees to larger container volumes earlier or that start trees in the container volume in which they will be marketed. Using larger container volumes to increase carbon assimilation and tree growth might be even more important in the northern hemisphere during late spring and early fall when daily maximum air temperatures are lower because the declination angles of the solar arc are lower (Martin et al., 1991). The lower solar declination angle increases the number of hours per day of direct insolation on container sidewalls.

Container shape can also influence heat load. Computer modeling was used to study the impact of container shape on RZT in two climates: Phoenix, AZ and Lexington, KY (Martin and Ingram, 1993). At both locations, RZT were predicted to be highest at the east and west container walls, halfway down the container profile, regardless of container height $(20-50 \mathrm{~cm})$. Predicted RZT adjacent to the container wall decreased as the wall tilt angle of the sidewall increased. As container height decreased, the container wall tilt angle necessary to lower the RZT at the center to at least $40{ }^{\circ} \mathrm{C}$ increased. The required increase in tilt angle of the sidewall to result in this threshold was greater for Phoenix than for Lexington, principally because of higher ambient air temperatures and solar radiation intensity.

Therefore, a high albedo due to color or material texture of containers will result in lower RZT. Containers with larger volumes have lower temperatures at the center of the container due to the distance from the container wall and RZT between those two points are moderated compared with smaller containers. Containers constructed of paper fiber have lower RZT due the insulative value of material and the reflective nature of the container surface. Container shape impacts RZT only if the incidence of solar radiation is affected.

Substrateproperties and watermanagement. Fretz (1972) reported that container substrate had little influence on RZT for plants wellwatered in full sun, but other elements in the system could have overwhelmed any potential differences due to substrate. For example, water content impacts temperature fluctuations and substrates differ in water-holding capacity and thus thermal diffusivity, or the rate of heat energy movement through a substance or object. Thermal diffusivity is impacted by the thermal conductivity, bulk density and specific heat capacity of individual components in the substrate/water/air matrix. Lin et al. (1994) reported a peat:bark compost substrate suffered the least temperature fluctuations of six substrates tested. Tollner et al. (1984) reported that an analytical procedure for calculating thermal conductivity of substrates agreed favorably with measured value, although variability in the data were noted.

At a volumetric water content of $10 \%$, there was little difference in thermal diffusivity in a pine bark substrate with varying ratios of sand up to $40 \%$ by volume (Martin and Ingram, 1991a). Increasing sand content decreased diffusivity when substrates were below $10 \%$ volumetric moisture content. Perhaps the $10 \%$ moisture content was enough to connect particles and increased the rate of heat energy movement between particles given that water is a better thermal conductor than sand. However, the substrate with the higher content sand had the lowest drainable air space and greatest diffusivity at water contents between $10 \%$ and $65 \%$. Therefore, the temperatures reached maximum more slowly and the maximum temperature was lower in a pine bark substrate supplemented with sand (4:1 or 3:2 pine bark:sand) when the volumetric water content ranged from $25 \%$ to $40 \%$.

Supraoptimal RZT treatments have resulted in greater water use for a range of woody plants (Barr and Pellett, 1972). Early work showed that irrigation requirements for plants grown in white containers were less than for plants grown in black or green containers (Haun and Fulmer, 1971). Irrigation has been suggested as a means to reduce the rate of RZT increase and the maximum daily RZT in containers. Keever and Cobb (1984b) found that application of water of a temperature significantly cooler than the substrate moderated RZT in small containers of substrate.

Results of field experiments revealed that to effectively cool the substrate in a $10-\mathrm{L}$ container would require a midday application of at least $3 \mathrm{~L}$ of water at $26^{\circ} \mathrm{C}$ (Martin and Ingram, 1991a). That volume of irrigation 
was almost three times the water holding capacity of the 4-pine bark:1-sand (v/v) substrate. Lower volumes of irrigation cooled the surface of the container but actually increased the temperature in the center of the container. It appears the heat from the top portion of the substrate was transferred to the center of the container. In other words, it took a high volume of water to flush the heat from the substrate. These results do not support the practice of "syringing" container-grown plants with a relatively small volume of water in an attempt to reduce RZT.

Timing of irrigation was reported to make a small difference in RZT (Warren and Builderback, 2002). Predawn irrigation lowered RZT slightly at 06:00-09:00 hr compared with afternoon irrigation. This would be expected as increasing a substrate to near water-holding capacity with cooler water would provide buffering potential for RZT increase. Time of daily maximum and maximum RZT in containers irrigated predawn, afternoon or throughout the day were similar and was 2 to $3{ }^{\circ} \mathrm{C}$ lower if water had been applied throughout the day compared with predawn or afternoon irrigation.

Increased daily irrigation volume did not offset reductions in root growth of 'Grande Naine' banana grown at RZT of 38 or $43{ }^{\circ} \mathrm{C}$ for $6 \mathrm{~h} \cdot \mathrm{d}^{-1}$ (Ramcharan et al., 1995). Root damage was apparently aggravated by increased irrigation in a $43{ }^{\circ} \mathrm{C}$ RZT treatment.

Incidence of solar radiation. Producing plants under shade has been shown to reduce RZT and increase plant growth in the southern United States. Reducing the overall solar radiation into the system, including direct radiation on container walls reduced RZT. Pittosporm, Rhododendron simsii Planch., and Cornus florida L. grew better in $47 \%$ shade compared with full sun in Florida, regardless of container color/type (Ingram, 1981). In the full sun, shoot and root dry weight was greater in all three genera if grown in white poly bags compared with black rigid containers. Plant growth impact of a white poly bag container compared with black rigid plastic container in shade was not as obvious as in full sun.

Barriers or reflective materials placed on the substrate surface failed to affect RZT (Fretz, 1971, 1972; Haun and Fulmer, 1971), supporting observations that solar radiation on container walls provides the vast majority of thermal energy into the system. The groundcover material on container beds was predicted to have minimal impact on RZT compared with direct solar incidence as modeled by (Martin and Ingram, 1992). White containers on black plastic resulted in RZT lower than black containers on a white shell groundcover but the impact of the ground surface were not separated from the impact of container color in Alabama (Keever and Cobb, 1984a). A white groundcover under plants with open canopies resulted in 2 to $4{ }^{\circ} \mathrm{C}$ higher RZT than black surfaces in Texas (Newman and Davies, 1988b).

A method used to reduce solar radiation on container walls is to space containers to provide mutual shading. Delaying of spacing from can-to-can to $30 \mathrm{~cm}$ apart when required by crowding reduced RZT and increased shoot and root growth of pittosporum and to a lesser degree in Ilex cornuta Lindl. \& Paxton. 'Dwarf Burford' (Laiche, 1985). Personal observations have shown that spacing in Florida before the shoot growth could provide mutual shading, or coincidental with heavy pruning in late spring or early summer, can result in RZT sufficient to kill roots of unacclimated plants. The arrangement of spacing (i.e., rectangular or triangular spacing), can impact RZT in containers if the canopies are sufficient and the spacing close enough to shade the western and/or southern exposures of containers.

Container shielded from direct solar radiation by overhead shade, reflective cover over the container sidewall or by inserting the production container in a larger container can reduce the heat load on containers and therefore reduce RZT to near ambient air temperature (Ingram, 1981; Keever and Cobb, 1984a; Martin et al., 1999; Ruter, 1996b). A brief review and discussion of temperature fluctuations in container substrates has been published, including the potential benefit on placing a container in a container to shield the production container from solar radiation, a precursor to pot-in-pot production systems (Ingram et al., 1989).

Placing the production container inside another container large enough to provide insulating effect of an air space reduces absorption of solar radiation drastically. The greatest impact comes from burying the protective "socket" container in the soil, but aboveground pot-in-pot systems also reduce RZT. Temperature fluctuations and extremes were greatest in a conventional container production system, at intermediate levels for aboveground pot-in-pot systems, and least in an in-ground pot-in-pot systems in South Carolina (London et al., 1998). Growth index and root dry weight were lower in the conventional container system.

Lethally high RZT for roots of Malus 'Donald Wyman' ('Donald Wyman' crabapple) and Syringa vulgaris L. 'Monge' were exceeded in containers positioned in aboveground plastic and bag-in-pot systems but not in pot-in-pot or field production systems in a northern U.S. location (Neal, 2010). Three years after transplanting 'Donald Wyman' crabapple in the field, there were no differences in the top growth regardless of production system treatment, indicating that these plants were able to overcome root damage sustained during production.

Martin et al. (1999) reported that mean maximum RZT in 19-L containers in Tempe, $\mathrm{AZ}$ was $19{ }^{\circ} \mathrm{C}$ higher in unshielded, aboveground container compared with containers in a below-ground pot-in-pot system. In this study, substrate moisture content was maintained at $90 \%$ of container capacity using a microirrigation system pulsed as directed by soil moisture sensors. Growth of Acacia smallii L. but not Cercidium floridum Benth. Ex A. Gary (blue palo verde) was enhanced by the pot-in-pot system measured one year after transplanting in the landscape. The predicted critical temperature for direct membrane injury was greater for blue palo verde. Young and Bachman (1996) found that RZT in the center of 57-L containers averaged $3.3{ }^{\circ} \mathrm{C}$ cooler and Ilex $\times$ attenuata 'Fosteri No. 2' root dry weights were greater in pot-in-pot than in exposed containers aboveground.

The predicted critical temperature for membrane thermostability of excised "Cully" river birch roots were greater in plants grown in conventional aboveground containers than plant produced in a pot-in-pot system in southern Georgia (Ruter, 1996b). These results indicate that river birch roots may be damaged by lower RZT after production in pot-in-pot systems compared with aboveground containers. Therefore, prevention of postharvest exposure of root systems to supraoptimal RZT may be even more important for plants grown in pot-in-pot than aboveground containers.

\section{Summary, Conclusions, and Implications for Future Research}

RZT in container-grown plants are often supraoptimal for plant survival and growth. Supraoptimal temperatures in the range of 46 to $57^{\circ} \mathrm{C}$ for 30 or more minutes cause direct injury to plant roots. Roots are more susceptible to high-temperature injury than stems and leaves. Direct injury is an immediate response to an extreme and is measureable at the cellular level. Critical RZT for direct injury are common in container production systems. Indirect injury caused by prolonged or repeated expose to sublethal yet supraoptimal temperatures in the range of 38 to $40{ }^{\circ} \mathrm{C}$ RZT for $6 \mathrm{~h} \cdot \mathrm{d}^{-1}$, impacts physiological processes such as photosynthesis, respiration, nutrient uptake and utilization, and hormone response and production.

The modeling work and field research with the physical container production system for nursery crops revealed the parameters that contribute most to the heat load and thus supraoptimal RZT. Production protocol changes that reduce the absorption of direct solar radiation by the container wall will have the greatest impact on reducing the limitations on growth caused by extreme RZT. Additional research is needed to explore creative ways of reducing the heat load on container sidewalls.

There are many unanswered questions related to the impact of supraoptimal RZT, as well as production protocols to minimize those impacts. Understanding more about differential plant response to supraoptimal RZT at the whole plant, cellular and molecular levels may lead to strategies to make plants more tolerant and systems to provide more optimal growth environments. Examples of areas needing research include recovery of roots exposed to supraoptimal temperatures with possible foci on wood callus development and membrane repair. Hormone synthesis, translocation and 
utilization in response to elevated RZT could answer many questions about modified plant architecture, physiological development and environmental responses as well as the underlying biochemical changes. A greater understanding of impacts of supraoptimal RZT on maintenance and growth respiration and the ability of one portion of a root system to compensate for a portion of roots exposed to supraoptimal RZT could lead to protocols to optimize outdoor production of plants in containers. The authors hope this review has stimulated interest in this area of research.

\section{Literature Cited}

Adam, M.L., P.M. Dixon, W.R. Graves, and J.M. Kelly. 2003. Net nitrate uptake by red maple is a function of root-zone temperature. J. Plant Nutr. 26:203-222.

Alexandrov, V.Y. 1964. Cytophysiological and cytoecological investigations of heat resistance of plant cells toward the action of high and low temperature. Q. Rev. Biol. 39:35-77.

Barr, W. and H. Pellett. 1972. Effect of soil temperature on growth and development of some woody plants. J. Amer. Soc. Hort. Sci. 97:632-635.

Donovan, L.A., K.W. McLeod, and K.L. Grant. 1990. Direct heat injury of roots of woody swamp species. J. Therm. Biol. 15:245-249.

Foster, W.J., D.L. Ingram, and T.A. Nell. 1991. Photosynthesis and root respiration in Ilex crenata 'Rotundifolia' at supraoptimal rootzone temperatures. HortScience 26:535-537.

Fretz, T.A. 1971. Influence of physical conditions on summer temperatures in nursery containers. HortScience 6:400-401.

Fretz, T.A. 1972. Media temperatures in nursery containers. University of Georgia, College of Agr., Expt. Sta. Res. Rpt. \# 121. 15 p.

Geater, C.A., A.S. Aiello, C.A. Dilley, G.R. Nonnecke, and W.R. Graves. 1997. High root-zone temperatures inhibit growth and development of Fragaria species. Fruit Varieties J. 51:94-101.

Graves, W.R. and M.N. Dana. 1987. A system to control root-zone temperature. HortScience 22:957-958.

Graves, W.R., M.N. Dana, and R.Y. Joly. 1991. Water use and growth of honey locust and treeof heaven at high root-zone temperature. HortScience 26:1309-1312.

Graves, W.R., R.J. Joly, and M.N. Dana. 1989. Root-zone temperature affects water status and growth of red maple. J. Amer. Soc. Hort. Sci. 114:406-410.

Graves, W.R. and L.C. Wilkins. 1991. Growth of honey locust seedlings during high root-zone temperature and osmotic stress. HortScience 26:1312-1315.

Gur, A., B. Bravado, and Y. Mizrahi. 1972. Physiological responses of apple trees to supraoptimal root temperatures. Physiol. Plant. 27:130-138

Gur, A., B. Bravdo, and J. Hepner. 1976a. The influence of root temperature on apple trees. III. The effect on photosynthesis and water balance. J. Hort. Sci. 51:203-210.

Gur, A., J. Hepner, and Y. Mizrahi. 1976b. The influence of root temperature on apple trees. I. Growth responses related to the application of potassium fertilizer. J. Hort. Sci. 51:181-193.

Gur, A., J. Hepner, and Y. Shulman. 1979. The influence of root temperature on apple trees. IV. The effect on the mineral nutrition of the tree. J. Hort. Sci. 54:313-321.
Gur, A., Y. Mizrahi, and R.M. Samish. 1976c. The influence of root temperature on apple trees. II. Clonal differences in susceptibility to damage caused by supraoptimal root temperature. J. Hort. Sci. 51:195-202.

Gur, A. and Y. Shulman. 1971. The influence of high root temperature on the potassium nutrition and on certain organic constituents of apple plants, p. 643-656. In: Samish, R.M. (ed.). Recent advances in plant nutrition. Gordon and Breach, New York, London, Paris

Hao, H., C. Jiang, S. Zhang, Y. Tang, and L. Shi 2012. Enhanced thermal-tolerance of photosystem II by elevating root zone temperature in Prunus mira Koehne seedlings. Plant Soil 353:367-378

Hardin, R.B., D.J. Eakes, J.L. Sibley, C.H. Gilliam, and G.J. Keever. 1999. Root membrane thermostability of Cornus florida $\mathrm{L}$. provenances. J. Therm. Biol. 24:237-240.

Harrison, R.H., T.H. Yeager, and D.L. Ingram. 1988. Growth response and nutrient uptake by Photinia $\times$ fraseri at supraoptimal root-zone temperatures. Proc. South. Nur. Assoc. Res. Conf. 33:68-70.

Haun, J.R. and J.P. Fulmer. 1971. Influence of perlite mulch and container color on soil temperature and moisture conditions of container-grown Ilex crenata. Amer. Nurseryman 14:69-71.

Huang, B., X. Liu, and Q. Xu. 2001. Supraoptimal soil temperatures induced oxidative stress in leaves of creeping bentgrass cultivars differing in heat tolerance. Crop Sci. 41:430-435.

Hume, H.H. 1953. Hollies. MacMilliam, New York.

Iba, K. 2002. Acclimative response to temperature stress in higher plants: Approaches of gene engineering for temperature tolerance. Annu. Rev. Plant Biol. 53:225-245.

Ingram, D.L. 1981. Characterization of temperature fluctuations and woody plant growth in white poly bags and conventional black containers. HortScience 16:762-763.

Ingram, D.L. 1985. Modeling high temperature and exposure time interactions in Pittosporum tobira root cell membrane thermostability. J. Amer. Soc. Hort. Sci. 110:470-473.

Ingram, D.L. 1986. Root cell membrane heat tolerance of two dwarf hollies. J. Amer. Soc. Hort. Sci. 111:270-272.

Ingram, D.L., B.H. Basford, W.J. Foster, and C. Ramcharan. 1990. Electronically controlled root heating tubes. HortScience 25:693-694.

Ingram, D.L. and D. Buchanan. 1981. Measurement of direct heat injury of roots of three woody plants. HortScience 16:769-771.

Ingram, D.L. and D. Buchanan. 1984. Lethal high temperatures for roots of three citrus rootstocks. J. Amer. Soc. Hort. Sci. 109:189-193.

Ingram, D.L., C.A. Martin, and J.M. Ruter. 1989. Effect of heat stress on container-grown plants. Proc. Intern. Plant Prop. Soc. 39:348-353.

Ingram, D.L. and C. Ramcharan. 1986. Heat tolerance of Ixora coccinea excised roots. Proc. Fla. State Hort. Soc. 99:246-248.

Ingram, D.L. and C. Ramcharan. 1988. 'Grande Naine' banana and Dracaena marginata 'Tricolor' root cell membrane heat tolerance. Fruits 43:29-33.

Ingram, D.L., C. Ramcharan, and D.W. Buchanan. 1986a. Critical high root-zone temperatures for container-grown citrus. Proc. Fla. State Hort. Soc. 99:214-217.

Ingram, D.L., C. Ramcharan, and T.A. Nell. 1986b Response of container-grown banana, ixora, citrus, and dracaena to elevated root temperatures. HortScience 21:254-255.
Ingram, D.L., P.G. Webb, and R.H. Biggs. 1986c. Interactions of exposure time and temperature on thermostability and protein content of excised Illicium parviflorum roots. Plant Soil 96:69-76.

Johnson, C.R. and D.L. Ingram. 1984. Pittosporum tobira response to container medium temperature. HortScience 19:524-525.

Jones, L.H. 1931. Effect of the structure and moisture of plant containers on the temperature of the soil contents. J. Agr. Res. 42:375-378.

Keever, G.J. and G.S. Cobb. 1984a. Container and production bed mulch effects on media temperature and growth of 'Hershey's Red' azalea. HortScience 19:439-441.

Keever, G.J. and G.S. Cobb. 1984b. Growth medium temperature in containers as influenced by moisture content. J. Environ. Hort. $2: 21-22$.

Klock, K.A., W.R. Graves, and H.G. Taber. 1996. Growth and phosphorus, zinc, and manganese content of tomato, muskmelon, and honey locust at high root-zone temperatures. J. Plant Nutr. 19:795-806.

Klock, K.A., W.R. Graves, and H.G. Taber. 1997. Root respiration and phosphorus nutrition of tomato plants grown at a 36 degrees $\mathrm{C}$ rootzone temperature. Amer. Soc. Hort. Sci. J. Amer. Soc. Hort. Sci. 122:175-178.

Kotak, S., J. Larkindale, U. Lee, P. von KoskullDöring, E. Vierling, and K.D. Scharf. 2007. Complexity of the heat stress response in plants. Curr. Opin. Plant Biol. 10:310-316.

Kramer, P.J. 1949. Plant and soil water relationships. McGraw Hill, New York, NY.

Kraus, H.T., S.L. Warren, and R.L. Mikkelsen. 2000. Container substrate temperature affect mineralization of composts. HortScience $35: 16-18$

Laiche, A.J., Jr. 1985. Effect of time of spacing on the growth of container-grown Ilex cornuta 'Dwarf Burford' Lindl. and Paxt. and Pittosporum tobira. Thumb. J. Environ. Hort. 3:2224.

Letey, J., L.H. Stolzy, N. Valoras, and T.E. Szuszkiewicz. 1963. Low soil oxygen most damaging to plants during hot weather. Calif. Agr. 17:15

Levitt, J. 1979. Response of plants to environmental stresses. Vol. 1. Chilling, freezing and high temperature stress. Academic Press, New York.

Lin, H.S., J.H. Lin, L.R. Chang, and C.H. Lin 1994. Studies on the alleviation of supraoptimal temperature stress of Shinseiki pear trees via media, shading and growth retardants. Special Publication Taichung District Agricult. Improvement Sta. 33:167-178.

Liu, X. and B. Huang. 2005. Root physiological factors involved in cool-season grass response to high soil temperature. Environ. Expt. Bot. 53:233-245.

London, J., G.D. Christenbury, R.T. Fernandez, and R.E. Young. 1998. Media temperatures and plant growth in above-ground and in-ground pot-in-pot container systems, Amer. Soc. Agr. Eng. Annual Intl. Meeting, Orlando, FL, 12-16 July 1998. Paper no. 987006.12 pp.

Lyles, J.L., D.W. Burger, and J.D. MacDonald. 1992. Short- and long-term heat stress effects on Phytophthora root rot of Hibiscus. HortScience 27:414-416.

MacDonald, J.D. 1991. Heat stress enhances Phytophthora root rot severity in container-grown chrysanthemums. J. Amer. Soc. Hort. Sci. 116:36-41.

Markham, J.W., D.J. Bremer, C.R. Boyer, and K.R. Schroeder. 2011. Effect of container color on 
substrate temperatures and growth of red maple and redbud. HortScience 46:721-726.

Martin, C.A. and D.L. Ingram. 1991a. Evaluation of thermal properties and effect of irrigation on temperature dynamics in container media. J. Environ. Hort. 9:24-28.

Martin, C.A. and D.L. Ingram. 1991b. Root growth of southern magnolia following exposure to high root zone temperatures. HortScience 26:370-371.

Martin, C.A. and D.L. Ingram. 1992. Simulation modeling of temperatures in root container media. J. Amer. Soc. Hort. Sci. 117:571-577.

Martin, C.A. and D.L. Ingram. 1993. Container dimension affects rooting medium temperature patterns. HortScience 28:18-19.

Martin, C.A., D.L. Ingram, and T.A. Nell. 1991. Growth and photosynthesis of Magnolia grandiflora 'St Mary' in response to constant and increased container volume. J. Amer. Soc. Hort. Sci. 116:439-445.

Martin, C.A., D.L. Ingram, and M.A. Jenks. 1991b. Response of southern magnolia to supraoptimal root-zone temperatures. J. Therm. Biol. 16 (5):281-285.

Martin, C.A., L.B. McDowell, and B. Shiela. 1999. Below ground pot-in-pot effects on growth of two southwest landscape trees was related to root membrane thermostability. J. Environ. Hort. 17:63-68.

Martin, C.A., T.A. Nell, and D.L. Ingram. 1989. Supraoptimal root-zone temperature alters growth and photosynthesis of holly and elm. J. Arboricult. 15:272-276.

Mathers, H.M. 2003. Summary of temperature stress issues in nursery containers and current methods of protection. HortTechnology 13: 617-624.

Mathers, H.M., S.B. Lowe, C. Scagel, D.K. Struve, and L.T. Case. 2007. Abiotic factors influencing root growth of woody nursery plants in containers. HortTechnology 17:151-162.

Murakami, Y., M. Tsuyama, Y. Kobayashi, H. Kodama, and K. Iba. 2000. Trienoic fatty acids and plant tolerance of high temperature. Science 287:476-479.

Neal, C.A. 2010. Crabapple and lilac growth and root-zone temperatures in northern nursery production systems. HortScience 45:30-35.

Nambuthiri, S., A. Fulcher, A.K. Koeser, R. Geneve, and G. Niu. 2015a. Moving toward sustainability with alternative containers for greenhouse and nursery crop production: A review and research update. HortTechnology 25: $8-16$.

Nambuthiri, S., R.L. Geneve, Y. Sun, X. Wang, R.T. Fernandez, G. Niu, G. Bi, and A. Fulcher. 2015 b. Substrate temperature in plastic and alternative nursery containers. HortTechnology 25:50-56.

Newman, S.E. and F.T. Davies, Jr. 1988a. High root-zone temperatures, mycorrhizal fungi, water relations, and root hydraulic conductivity of container-grown woody plants. J. Amer. Soc. Hort. Sci. 113:138-146.

Newman, S.E. and F.T. Davies, Jr. 1988b. Influence of field bed position, ground surface color, mycorrihizal fungi, and high root-zone temperature in woody plant container production. Plant Soil 112:29-35.

Papineau, A. and C.A. Neal. 2015. Root zone temperature and growth response of river birch (Betula nigra) in five above-ground pot production systems. HortScience (in press).

Pellett, H., C. Anderson, and C. Allen. 1973. A simplified soil temperature regulation system. HortScience 4:64-65.

Percival, D.C., M.J. Tsujita, and J.T.A. Proctor. 1996. Whole-plant net $\mathrm{CO}_{2}$ exchange of raspberry as influenced by air and root-zone temperature, $\mathrm{CO}_{2}$ concentration, irradiation, and humidity. J. Amer. Soc. Hort. Sci. 121:838845 .

Rachmilevitch, S., H. Lambers, and B. Huang. 2008. Short-term and long-term root respiratory acclimation to elevated temperatures associated with root thermotolerance for two Agrostis grass species. J. Expt. Bot. 59:38033809 .

Ramcharan, C., D.L. Ingram, T.A. Nell, and J.E. Barrett. 1991. Fluctuations in leaf carbon assimilation as affected by root-zone temperature and growth environment. HortScience 26 1200-1202.

Ramcharan, C., D.L. Ingram, T.A. Nell, and J.E. Barrett. 1995. Interactive effects of root-zone temperature and irrigation volume on banana vegetative growth in two environments. Fruits 50:225-232.

Ruter, J.M. 1995. Growth of Coreopsis and Plumbago in plastic and $\mathrm{Cu}\left(\mathrm{OH}_{2}\right)$-impregnated fiber containers. HortTechnology 5:300-302.

Ruter, J.M. 1996a. Growth and flowering of three garden chrysanthemum cultivars produced in plastic or copper-impregnated fiber containers. J. Environmental Horticulture 14:191-193.

Ruter, J.M. 1996b. High-temperature tolerance of Heritage river birch roots decreased by pot-inpot production systems. HortScience 31:813814.

Ruter, J.M. 1997. Boost perennial growth with copper-impregnated fiber pots. Greenhouse Production News 7:28-29.

Ruter, J.M. 1999. Fiber pots improve survival of 'Otto Luyken' laurel. Proc. South. Nur. Assoc. Res. Conf. 44:53-54.

Ruter, J.M. 2000a. Biodegradable fiber containers improve the growth of two daylily cultivars. Acta Hort. 517:271-274.

Ruter, J.M. 2000b. Container design influences offset production of Hosta. Proc. South. Nur. Assoc. Res. Conf. 45:87-88.

Ruter, J.M. 2000c. Cross-country containers. Amer. Nurseryman 191:26-30.

Ruter, J.M. 2000d. Influence of fiber and plastic pots on growth of five ericaceous species. Proc. South. Nur. Assoc. Res. Conf. 45:85-86.

Ruter, J.M. 2001. Fiber pots with Spin Out for nursery crop production. Proc. Intern. Plant Prop. Soc. 50:509-512.

Ruter, J.M. and D.L. Ingram. 1990. 14Carbonlabeled photosynthate partitioning in Ilex crenata 'Rotundifolia' at supraoptimal root-zone temperatures. J. Amer. Soc. Hort. Sci. 115: 1008-1013.
Ruter, J.M. and D.L. Ingram. 1991. Root respiratory characteristics of 'Rotundifolia' holly under supraoptimal temperatures. J. Amer. Soc. Hort. Sci. 116:560-564.

Ruter, J.M. and D.L. Ingram. 1992. High root-zone temperatures influence $\mathrm{RuBisCO}$ activity and pigment accumulation in leaves of 'Rotundifolia' holly. J. Amer. Soc. Hort. Sci. 117:154 157.

Self, R.L. and H.S. Ward. 1956. Effects of high soil temperature on root growth of loquat seedlings in nursery containers. Plant Disease Reporter 40:957-960.

Sibley, J.L., J.M. Ruter, and D.J. Eakes. 1999. Root membrane thermostability of red maple cultivars. J. Therm. Biol. 24:79-89.

Sullivan, C.Y. 1972. Mechanisms of heat and drought resistance in grain sorghum and methods of measurement, p. 247-264. In: Rao, N.G.P. and L.R. House (eds.). Sorghum in the seventies. Oxford \& I.B.H. Publishing Co., New Delhi, India.

Tollner, W.E., B.P. Verma, and S. Vandergrift. 1984. Thermal conductivity of artificial potting soils. Proc. of the 1984 Summer Meeting of Amer. Soc. of Ag. Engineers Paper No. 841086.

Verma, B.P. 1979. Container design for reducing root-zone temperature. Proc. South. Nur. Assoc. Res. Conf. 24:179-182.

Wahid, A., S. Gelani, M. Ashraf, and M.R. Foolad. 2007. Heat tolerance in plants: An overview. Environ. Expt. Bot. 61:199-223.

Wang, Z., J. Pote, and B. Huang. 2003. Responses of cytokinins, antioxidant enzymes, and lipid peroxidation in shoots of creeping bentgrass to high root-zone temperatures. J. Amer. Soc. Hort. Sci. 128:648-655.

Warren, S.L. and T.E. Builderback. 2002. Timing of low pressure irrigation affects plant growth and water utilization efficiency. J. Environ. Hort. 20:184-188.

Wilkins, L.C., A.M. Townsend, and W.R. Graves. 1995. Responses to high root-zone temperature among cultivars of red maple and Freeman maple. J. Environ. Hort. 13:82-85.

Wong, T.L., R.W. Harris, and R.E. Fissell. 1971. Influence of high soil temperatures on five woody-plant species. J. Amer. Soc. Hort. Sci. 96:80-82.

Yeager, T.H., R.H. Harrison, and D.L. Ingram. 1991. 'Rotundifolia' holly growth and nitrogen accumulation influenced by supraoptimal root-zone temperatures. HortScience 26:13871388.

Young, K. and K.R.W. Hammett. 1980. Temperature patterns in exposed black polyethylene plant containers. Agr. Meteorol. 21:165-172.

Young, R.E. and G.R. Bachman. 1996. Temperature distribution in large, pot-in-pot nursery containers. J. Environ. Hort. 14:170-176.

Yusof, I.M., J.F. Gerber, and D.W. Buchanan. 1969. The response of avocado and mango to soil temperature. J. Amer. Soc. Hort. Sci. 94:619-621. 